Актуальные аспекты обеспечения эпидемиологического благополучия по чуме населения Республики Алтай

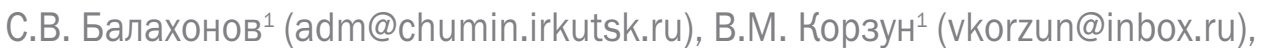 \\ С.А. Косилко (epidotdel.irk@mail.ru), Е.П. Михайлов² ${ }^{2}$ л.В. щучинов ${ }^{3}$, А.И. Мищенко², \\ И.В. Зарубин ${ }^{3}$ (Rpn_RA@mail.gorny.ru), E.Н. Рождественский², А.В. Денисов² \\ (chuma@mail.gorny.ru)
}

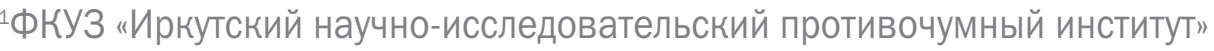 \\ Роспотребнадзора \\ ФКУЗ «Алтайская противочумная станция» Роспотребнадзора, г. Горно-Алтайск \\ ${ }^{3}$ Управление Роспотребнадзора по Республике Алтай, г. Горно-Алтайск
}

\title{
Резюме
}

Представлены материалы, характеризующие современную эпизоотическую и эпидемиологическую ситуацию в Горно-Алтайском высокогорном природном очаге чумы, в котором в 2012 году впервые обнаружен возбудитель чумы основного подвида. Его агрессивная интродукция в поселения серого сурка на Юго-Восточном Алтае привела к спорадическим случаям заболевания чумой среди местного населения в 2014 и 2015 годах. Проведенный комплекс организационных, профилактических и противоэпидемических мероприятий не позволили допустить формирования антропонозного пути распространения этой опасной инфекционной болезни за пределы природного очага. В настоящее время разработана и реализуется программа мероприятий по минимизации риска возникновения осложнений санитарно-эпидемиологической обстановки по чуме в Республике Алтай. Ключевые слова: чума, заболевание людей, интродукция возбудителя чумы основного подвида, Горный Алтай, природный очаг, эпизоотическая ситуация, профилактические и противоэпидемические мероприятия

\section{Actual Aspects of Epidemiological Well-Being Support Anti-PLAgue for Population in Altai Republic}

S.V. Balakhonov ${ }^{1}$ (adm@chumin.irkutsk.ru), V.M. Korzun ${ }^{1}$ (vkorzun@inbox.ru), S.A. Kosilko (epidotdel.irk@mail.ru), E.P. Mikhailov², L.V. Shchuchinov ${ }^{3}$, A.I. Mishchenko², I.V. Zarubin³ (Rpn_RA@mail.gorny.ru), E.N. Rozhdestvensky², A.V. Denisov²

${ }^{1}$ Federal Budgetary Healthcare Facility "Irkutsk Antiplague Research Institute" of Federal Service for Surveillance on Consumer Rights Protection and Human Wellbeing, adm@chumin.irkutsk.ru

${ }^{2}$ Federal Budgetary Healthcare Facility "Altai Antiplague Station" of Federal Service for Surveillance on Consumer Rights Protection and Human Wellbeing, Gorno-Altaisk

${ }^{3}$ Administration of of Federal Service for Surveillance on Consumer Rights Protection and Human Wellbeing in Altai Republic, Gorno-Altaisk

\section{Abstract}

Relevance. Despite significant advances in modern medicine in the treatment of infectious diseases, the plague has not lost its relevance and is one of the socially significant epidemic threats as a particularly dangerous infection. Every year, there are nearly 2.5 thousand cases of plague in the world, and the mortality rate $7-13 \%$.

Goal. Analysis of the current epizootic and epidemiological situation of the plague, and to determine the optimal set of preventive measures to ensure epidemiological welfare of population of the Republic of Altai on this particularly dangerous infectious disease.

Materials and methods. Used the results of monitoring in 1961 - 2015 years of Gorno-Altai natural foci of plague. For more than 50 years bacteriologically were examined more than 290 thousand. small mammals, more than 1545 thousand fleas, isolated 2435 strains of the plague pathogen.

Results. In recent years, the Gorno-Altai foci of plague most active of the 11 natural focis, located in Russia. On the Gorno-Altai territory in 2001 to 2014 isolated 801 strain of the pathogen, in 2015 - 23 strains, including 17 main subspecies.

currently in the Gorno-Altai natural foci of plague there is a joint circulation of the two subspecies of the plague microbe: $Y$. pestis subsp. altaica and $Y$. pestis subsp. pestis.

In September 2014 the first time since the detection foci of plague (1961) recorded the local human case of bubonic plague. in August 2015 identified a new case of the plague

Conclusions. Introduction of the plague pathogen main subspecies into the ecosystem of the Gorno-Altaisk natural foci of plague greatly increases the possibility of dangerous epidemiological situation

Key words: plague, human case, introduction of Yersinia pestis basic subspecies, Mountain Altai, a natural focus, epizootic situation, preventive and anti-epidemic actions 


\section{Введение}

Несмотря на значительные достижения современной медицины в лечении инфекционных болезней, чума не утратила своей актуальности и представляет собой одну из социально значимых эпидемических угроз как особо опасная инфекция. Ежегодно в мире регистрируется около 2,5 тыс. больных, а летальность колеблется в пределах 7 - 13\% [1]. Особенностью современных эпидемических проявлений чумы является их территориальная приуроченность к природным очагам инфекции, а заболеваемость связана с интенсивностью протекания эпизоотий в популяциях носителей и степенью контакта населения с компонентами экологических систем очагов [2].

Эффективная система эпидемиологического надзора позволяет на протяжении длительного периода держать эпидемиологическую ситуацию по чуме под контролем, хотя риски возникновения спорадических случаев присутствуют постоянно. Наглядным примером этому служит зарегистрированный в 1979 году случай чумы (на фоне 25-летнего периода благополучия) в п. Артезиан (Республика Калмыкия), который связан с резким повышением эпизоотической активности Прикаспийского песчаного природного очага инфекции [3].

Значительное нарастание в Горно-Алтайском высокогорном природном очаге эпизоотической активности в поселениях монгольской пищухи (Ochotona pallasi), являющейся основным носителем возбудителя чумы, и агрессивная интродукция основного подвида Yersinia pestis subsp. pestis в популяцию серого (алтайского) сурка (Marmota baibacina) на Юго-Восточном Алтае привели к существенному напряжению эпидемиологической ситуации [4 - 7], что проявилось двумя спорадическими случаями заболевания людей бубонной чумой в Кош-Агачском районе Республики Алтай (2014, 2015 гг.) [5, 7]. Сложившаяся ситуация требует поиска новых подходов и скоординированных усилий учреждений Роспотребнадзора и других ведомств для минимизации риска эпидемических осложнений среди населения республики.

Цель работы - анализ современной эпизоотической и эпидемиологической ситуаций по чуме и определение оптимального комплекса профилактических мероприятий по обеспечению эпидемиологического благополучия населения Республики Алтай по этой особо опасной инфекционной болезни.

\section{Материалы и методы}

В работе использованы многолетние (1961 2015 гг.) результаты мониторинга Горно-Алтайского природного очага чумы, проводимого Алтайской противочумной станцией и Иркутским научно-исследовательским противочумным институтом. За этот более чем 50-летний период на зараженность чумой исследовано бактериологически более 290 тыс. мелких млекопитающих, более 1545 тыс. блох, изолировано 2435 штаммов возбудителя.
Проанализированы карты эпидемиологического расследования случаев заболевания чумой людей, отчетная и первичная документация ФКУЗ “Алтайская противочумная станция", материалы ФКУЗ "Иркутский научно-исследовательский противочумный институт".

При обработке данных использовался метод ретроспективного эпидемиологического анализа.

\section{Результаты и обсуждение}

В последние годы Горно-Алтайский очаг чумы наиболее активный из 11 природных очагов, расположенных на территории РФ как в эпидемическом, так и эпизоотическом отношении. На его территории с 2001 по 2014 год изолирован 801 штамм возбудителя, в 2015 году - 23 штамма, в том числе 17 основного подвида. Выраженное увеличение эпизоотической активности в этом очаге отмечается с начала 1990-х годов [4, 6]. Постоянно высокая активность очага наблюдается в текущем столетии. Регистрируемые ежегодно площади эпизоотий колеблются в пределах 232 и 870 кв. км (среднее - 616 кв. км). За последние полтора десятилетия энзоотичная по чуме территория возросла в два раза и к 2015 году составила 2020 кв. км. Необходимо подчеркнуть, что до 2012 года в очаге отмечалась циркуляция возбудителя чумы только алтайского подвида. Впервые за весь период наблюдений в июне 2012 года в Горно-Алтайском природном очаге чумы был изолирован высоковирулентный штамм чумного микроба основного подвида [8], в 2014 - 2 штамма, в 2015 - 17 штаммов основного подвида. Из 20 штаммов Y. pestis subsp. pestis, изолированных к настоящему времени в очаге, 17 получены от серого сурка и его блох. Кроме того в 2015 году в 34 пробах полевого материала методом ПЦР обнаружена ДНК чумного микроба основного подвида.

Интродукция возбудителя основного подвида в экологическую систему очага привела к образованию нового (четвертого) мезоочага (Талдуаирского) в отрогах хребта Чихачева и горного массива Талдуаир, где в 2015 году изолировано два штамма чумного микроба основного подвида от сурков. В 2014 и 2015 годах в трех пробах полевого материала от сурков методом ПЦР обнаружена ДНК Ү. pestis subsp. pestis. Ранее проявлений эпизоотий чумы в этом районе не регистрировали. Также возбудитель чумы основного подвида обнаружен в двух из трех известных к 2015 году мезоочагах (в Уландрыкском и Тархатинском).

Совокупность полученных за последние четыре года рассматриваемого периода данных по выявлению возбудителя чумы основного подвида и его ДНК позволяет констатировать, что в настоящее время в Горно-Алтайском природном очаге чумы наблюдается совместная циркуляция двух подвидов чумного микроба: Y. pestis subsp. altaica и Ү. pestis subsp. pestis. Анализ сведений по эпизоотологическому мониторингу очага позволил заключить, что интро- 
дукция возбудителя чумы основного подвида из Северо-Западной Монголии произошла недавно [6]. Основным носителем возбудителя при циркуляции основного подвида является серый сурок.

В настоящее время отмечается высокая эпизоотическая активность на большей части очага и стремительный рост эпидемического потенциала, обусловленный интродукцией возбудителя чумы основного подвида, который уже явился причиной спорадических случаев заболевания чумой среди жителей Кош-Агачского района [5, 7]. Нами ранее неоднократно акцентировалось внимание на возрастающем риске возникновения эпидемических осложнений в очаге в связи ростом его эпизоотической активности [4, 8 - 10].

В сентябре 2014 году впервые со времени обнаружения очага (1961г.) зарегистрирован местный случай заболевания человека бубонной чумой. Заражение произошло во время разделки больного сурка, добытого в результате незаконного охотпромысла в долине р. Сербисту, расположенной на северном макросклоне Южно-Чуйского хребта. Клинический диагноз бубонной чумы был подтвержден изоляцией культуры возбудителя чумы основного подвида из пунктата бубона в левой подмышечной области больного. Кроме того, из замороженной тушки сурка, изъятого в доме заболевшего, также был выделен чумной микроб этого же подвида [5, 11].

Несмотря на проведенный комплекс профилактических и противоэпидемических мероприятий, в августе 2015 года выявлен новый случай чумы [7]. Заражение местного жителя, привитого против чумы в апреле 2015 года, произошло при разделке серых сурков, добытых в урочищах Анаяк и СазынКёль в долине р. Елангаш, удаленных на 10 км от урочища Сербисту. Диагноз "Бубонная чума" был установлен по данным эпиданамнеза, клинической картине и подтвержден нарастанием титров специфических антител к фракции 1 чумного микроба в 10 раз на 9 сутки от начала заболевания. Необходимо отметить, что из проб клинического материала, взятого от больного, возбудитель чумы выделить не удалось. В тоже время от изъятых в доме заболевшего двух замороженных тушек сурков выделены культуры чумного микроба основного подвида.

Следует подчеркнуть, что в обоих случаях заражение произошло при разделке добытых сурков, через поврежденные кожные покровы с формированием сходной клинической картины. Однако тяжесть течения болезни во втором случае была значительно легче, что, вероятно, связано с ранним обращением за медицинской помощью, высокой настороженностью медицинского персонала и заражением, произошедшим на фоне формирования специфического поствакцинального иммунитета (титр специфических антител на момент обращения составлял в РНГА/РНАг 1:32). Отметим, что сезон, источник, путь заражения и клиническая картина у больных чумой в Кош-Агачском районе Республики Алтай весьма схожи с таковыми на энзоотичных по чуме территориях Монголии $[12,13]$.

Важно, что спорадических случаев заболеваний чумой на энзоотичных территориях на фоне высокой эпизоотической активности избежать достаточно сложно, особенно при наличии браконьерского не контролируемого промысла эпидемически значимых животных. Кроме того, в условиях совершенствования бытовой техники и электрификации отдаленных поселений сформировался новый фактор эпидемического риска распространения чумы на этой территории и за ее пределы, связанный с возможностью длительного сохранения тушек сурков, в том числе и контаминированных чумным микробом, при низкой температуре в условиях бытовых холодильников или морозильных камер. Известны случаи сохранения возбудителя чумы в течение года в замороженном мясе [14]. Отметим, что употребление в пищу сурочьего мяса традиционно для коренных жителей Республики Алтай, и, более того, оно является деликатесом и сохраняется для особо торжественных случаев, а также может выступать в качестве подарка уважаемым гостям. Наглядным примером возникновения такого риска служат события, связанные со случаями заболеваний людей в Кош-Агачском районе. Так, три тушки сурков, одна из которых была заражена чумой, изъятых в 2014 году из холодильника в доме у заболевшего чумой А. в с. Мухор-Тархата, были специально добыты и хранились для праздничного застолья по поводу встречи сына из армии. В 2015 году две тушки сурков (обе заражённые чумным микробом), изъятые из холодильника в доме больного М. в с. Кызыл-Таш, предназначались для новогоднего праздника. Таким образом, эпидемические осложнения по чуме могут происходить как в нетипичный для этого заболевания сезон года, так и далеко за пределами энзоотичной по чуме территории, где источником может послужить контаминированное чумным микробом мясо сурка.

Также следует акцентировать внимание на том, что интродукция возбудителя чумы основного подвида в экосистему Горно-Алтайского природного очага существенно повысила риск вовлечения в эпизоотический процесс верблюдов, выпасающихся на эндемичной территории, что, в свою очередь, значительно увеличивает возможность возникновения эпидемических осложнений, источником которых может послужить больное или погибшее от чумы животное.

Существенное влияние на повышение рисков возникновения эпидемических осложнений по чуме в Республике Алтай и угрозы вывоза возбудителя за пределы природного очага может оказать реализация двух крупных проектов: развитие "Национального парка "Сайлюгемский" Министерства природных ресурсов и экологии Российской Федерации и предполагаемое строительство газопровода “Сила Сибири-2" из РФ в КНР. 
Перспективный план развития Национального парка "Сайлюгемский” предусматривает включение в него обширных энзоотичных участков ГорноАлтайского природного очага на склонах хребтов Сайлюгем, Чихачёва, Курайского, Южно-Чуйского, где наблюдается активная экспансия возбудителя чумы основного подвида и зарегистрированы случаи заражения людей этой инфекционной болезнью.

Учитывая изменения статуса этой территории, возникают определенные трудности в осуществлении здесь мониторинга эпизоотической активности и проведении мероприятий по неспецифической профилактике (дератизация, дезинсекция). Кроме того, интенсивное развитие экологического туризма, как национального, так и международного, в границах парка "Сайлюгемский" и связанное с этим резкое увеличение количества людей, посещающих участки активных эпизоотии чумы, тесный контакт человека с компонентами паразитарной системы очага чревато возникновением как спорадических случаев чумы среди людей, так и эпидемических вспышек при реализации антропонозного пути распространения возбудителя. В этой ситуации значительно возрастает риск вывоза болезни за пределы энзоотичной зоны в крупные административные центры как на территории Сибири, так и в европейскую часть России, что, в свою очередь, может привести к возникновению чрезвычайных ситуаций эпидемиологического характера с серьезным социально-экономическим ущербом.

В связи с подписанием Соглашения с КНР ведутся подготовительные работы по строительству магистрального газопровода "Сила Сибири-2" для организации поставок российского газа в Китай. Протяженность газопровода по территории Республики Алтай составит 591 километр, из них 256 км - по территории энзоотичного по чуме КошАгачского района. В строительстве газопровода будут участвовать более 2,5 тыс. человек, работы планируется организовать вахтовым методом с привлечением трудовых ресурсов из соседних регионов, что создает дополнительные эпидемические угрозы.

В настоявшее время туризм является одним из приоритетных экономических направлений в Республике Алтай. Это закреплено в Стратегии социально-экономического развития Сибири до 2028 года. В Республике Алтай принят Закон "О туризме в Республике Алтай" (2008 г.) и государственная программа "Развитие внутреннего и выездного туризма". В ее реализации участвует 86 туристических фирм, специализирующихся на оказании экскурсионных услуг, организации многодневных туристических походов. В туристический сезон 2015 года Республику Алтай посетило около 1,7 млн человек, в том числе около 15 тыс. непосредственно Кош-Агачский район. В основном это жители крупных городов Сибири (гг. Новосибирск,
Барнаул) и европейской части РФ (до 11,5\% от общего потока) (Москва, Санкт-Петербург) [15].

В связи с вступлением в силу 14.11.2014 г. Соглашения между Правительствами Российской Федерации и Монголии об условиях взаимных поездок граждан этих стран значительно увеличилось количество иностранных граждан, въезжающих в Российскую Федерацию в пункте пропуска "Ташанта" (в два раза). В 2014 году количество физических лиц, въезжающих на территорию РФ из Монголии, составляло 28 930, в 2015 - 55165 человек и число транспортных средств соответственно - 8315 и 16801. В этих условиях значительно повышается риск завоза возбудителя чумы на территорию Республики Алтай из Монголии, где существуют активные природные очаги этой болезни и практически ежегодно регистрируются спорадические случаи чумы у людей [13].

Bce вышеизложенное диктует необходимость разработки новых методических подходов к организации и проведению эпидемиологического надзора за чумой на территории Кош-Агачского района Республики Алтай. Это включает в себя оптимизацию межведомственного взаимодействия органов местного самоуправления, учреждений, осуществляющих противоэпидемические мероприятия, ветеринарной службы; совершенствование тактики эпизоотологического обследования и медицинского наблюдения за постоянным и временным населением, проживающим на энзоотичной территории; повышение эффективности специфической и неспецифической профилактики; активизацию информационно-разъяснительной работы.

Иркутским НИПчИ, Алтайской ПчС, Управлением Роспотребнадзора по Республике Алтай, Центром гигиены и эпидемиологии в Республике Алтай, Комитетом ветеринарии с Государственной ветеринарной инспекцией Республики Алтай, Правительством Республики Алтай при участии РосНИПчИ "Микроб" в 2014 - 2015 годах подготовлен большой пакет документов, определяющих комплекс мероприятий по снижению риска возникновения спорадических случаев чумы и недопущению эпидемических осложнений. Среди них являются основополагающими:

- «Научно-исследовательская программа эпизоотологических обследований природного очага чумы и других природно-очаговых инфекций в Кош-Агачском районе Республики Алтай на 2015 - 2017 годы", целью которой является научное обоснование мониторинга активности Горно-Алтайского природного очага чумы и очагов других опасных природно-очаговых инфекций. Выявление новых территорий циркуляции чумного микроба. Обеспечение эпидемиологического благополучия населения Кош-Агачского района Республики Алтай путем повышения эффективности организационных, профилактических, противоэпидемических мероприятий, основанных на всестороннем научном анализе 
полученных результатов полевых и лабораторных исследований.

- «Республиканская целевая программа по снижению рисков возникновения эпидемических осложнений на территории Горно-Алтайского природного очага чумы на 2016 - 2018 годы", которая направлена на предупреждение заболеваемости чумой населения Республики Алтай и включает в себя 65 мероприятий различного характера. Средства, необходимые для ее реализации, заложены в республиканский бюджет на 2016 год и уже частично освоены на проведение профилактических, санитарно-просветительных мероприятий.

В связи с резким изменением эпизоотической и эпидемической ситуации и формированием очага смешанного (сурочье-пищухового) типа специалистами Алтайской ПЧС и Иркутского НИПЧИ были внесены существенные коррективы в тактику эпизоотологического обследования очага. Сезонная активизация Горно-Алтайского природного очага чумы пищухового типа с циркуляцией возбудителя алтайского подвида происходит в осенний период [4]. Тогда как особенностью горных природных очагов, расположенных в Монголии, Туве и на Тянь-Шане и сходных по природно-климатическим и ландшафтным характеристикам с Юго-Восточным Алтаем, в которых циркулирует чумной микроб основного подвида, а носителями являются главным образом сурки и суслики, является летняя активизация эпизоотического процесса [16 - 19]. Поэтому, после выявления в Горно-Алтайском очаге возбудителя чумы основного подвида, особое внимание стало уделяться обследовательским работам в весенний и летний периоды с акцентом на поиск эпизоотий чумы в поселениях серого сурка и длиннохвостого суслика, в первую очередь на территории, прилегающей к Монголии и в верховьях рек, стекающих с хребтов. Значительно увеличены сроки обследовательских работ. Такой подход уже дал положительные результаты в 2015 году, когда были выявлены интенсивные и обширные эпизоотии в поселениях серого сурка на трех изолированных территориях, что позволило установить реальную на настоящий момент площадь распространения Y. pestis subsp. pestis.

Учитывая сложность эпидемической ситуации, были увеличены объемы вакцинации и расширены контингенты, подлежащие ей на территории Кош-Агачского района. Так, количество привитых в 2013 году составило 809 человек, в 2014 - 1857, в 2015 году возросло более чем в 2 раза (4163 человек) по сравнению с предыдущим годом, в 2016 году запланирована вакцинация 5600 человек. Таким образом, специфической профилактикой будет охвачено около 30\% населения района. На случай обострения эпидемической ситуации предусмотрено создание неснижаемого запаса противочумной вакцины в количестве 4000 накожных доз. Кро- ме того, проведена вакцинация живой противочумной вакциной "Кэмел-ПРО Р.С." производства ФКП "Ставропольская биофабрика" (Ставропольский край) всего поголовья верблюдов, выпасающихся на энзоотичной территории в Кош-Агачском районе Республики Алтай.

Для повышения эпидемической настороженности специалистов общей медицинской сети и обеспечения раннего выявления больных с подозрением на чуму на всех этапах оказания медицинской помощи с медицинскими работниками были проведены семинары. Готовность лечебно-профилактических организаций и оперативных служб района к проведению комплекса противоэпидемических мероприятий при выявлении больных с диагнозом, не исключающим чуму, была проверена в ходе тренировочных учений с вводом условного больного. Для повышения эффективности обучения медицинского персонала специалистами Иркутского противочумного института подготовлен учебный фильм “Организация и проведение первичных противоэпидемических мероприятий при выявлении опасного инфекционного заболевания в лечебнопрофилактической организации поликлинического профиля", который передан в Управление Роспотребнадзора по Республике Алтай.

Учитывая, что источником заражения людей чумой явились сурки, добытые в результате охотпромысла, во всех населенных пунктах района проведены сходы местного населения для информирования о сложившейся эпизоотолого-эпидемической ситуации, с разъяснением опасности добычи этих животных. Кроме того, на уровне исполнительной власти республики принято постановление, запрещающее охотпромысел серого сурка на энзоотичной по чуме территории.

Все это способствовало раннему выявлению заболевшего в августе 2015 года и предотвращению развития эпидемического осложнения с формированием антропонозного пути распространения чумы среди местного населения.

Важнейшим направлением работы по обеспечению эпидемиологического благополучия населения по чуме является минимизация рисков завоза возбудителя с сопредельной энзоотичной территории Монголии. Это затруднено отсутствием объективной информации об эпизоотической ситуации по чуме на сопредельной территории данной страны, так как мониторинг ее на постоянной основе отсутствует. Последние сведения были получены в 1990 году, поэтому в 2015 году Иркутским НИПЧИ и Алтайской ПЧС при участии Управления Роспотребнадзора по Республике Алтай разработан проект программы "Изучение современного состояния трансграничного Сайлюгемского природного очага чумы и снижение возможных эпидемиологических рисков на его территории" и подготовлено его финансовое и материально-техническое обоснование. Этот проект программы поддержан Национальным центром по изучению зоонозных инфекций Монголии и пред- 
ставлен в Федеральную службу по надзору в сфере защиты прав потребителей и благополучия человека, где получил одобрение. В настоящее время он включен самостоятельным разделом в программу по развитию сотрудничества с сопредельными государствами для снижения рисков завоза и распространения на территории Российской Федерации чумы из трансграничных природных очагов, представленную для утверждения в Правительство Российской Федерации.

Таким образом, проведенный комплекс организационных, профилактических и противоэпидемических мероприятий позволил, несмотря на возникновения спорадических случаев чумы, не допустить развития эпидемических осложнений, формирования антропонозного пути распространения этой опасной инфекционной болезни и вывоза ее за пределы энзоотичной территории. В тоже время для обеспечения эпидемического благополучия населения республики Алтай необходимо решить следующие задачи:
- повысить материально-техническое оснащение, кадровое и финансовое обеспечение Алтайской ПчС;

- обеспечить готовность лечебно-профилактической службы Республики Алтай к раннему выявлению больных и подозрительных на заболевание чумой на всех этапах оказания медицинской помощи;

- обеспечить реализацию комплекса мероприятий, направленных на снижение риска заражения человека чумой на энзоотичной территории;

- обеспечить реализацию комплекса мероприятий по профилактике заражения чумой верблюдов, выпасаемых на территории Горно-Алтайского природного очага;

- создать эффективную систему мониторинга эпизоотической и эпидемической ситуации в трансграничных природных очагах чумы путем реализации международных программ сотрудничества.

\section{Литература}

1. Plague Manual: Epidemiology, Distribution, Surveillance and Control. WHO, Geneva; 1999. Доступно на: http://www.who.int/emc.

2. Кокушкин А.М. Социальные и биологические аспекты эпидемиологии чумы: Автореф. дис. ... д-ра мед. наук. Саратов; 1995.

3. Попов Н.В., Безсмертный В.Е., Матросов А.Н., Князева Т.В., Кузнецов А.А., Федоров М.Ю. и др. Эпизоотическая активность природных очагов чумы Российской Федерации в 2014 г. и прогноз на 2015 г. Проблемы особо опасных инфекций. 2015; 1: 10 - 17.

4. Балахонов С.В., Корзун В.М., ред. Горно-Алтайский природный очаг чумы: Ретроспективный анализ, эпизоотологический мониторинг, современное состояние. Новосибирск: Наука-Центр; 2014.

5. Кутырев В.В., Попова А.Ю., Ежлова Е.Б., Демина Ю.В., Пакскина Н.Д., Щучинов Л.В. и др. Заболевание человека чумой в Горно-Алтайском высокогорном природном очаге в 2014 г. Сообщение 1. Эпидемиологические и эпизоотологические особенности проявлений чумы в Горно-Алтайском высокогорном (Сайлюгемском) природном очаге чумы. Проблемы особо опасных инфекций. 2014; 4: 9 - 16.

6. Корзун В.М., Балахонов С.В., Чипанин Е.В., Денисов А.В., Михайлов Е.П., Мищенко А.И. и др. Формирование, развитие и функционирование природного очага чумы в Горном Алтае. Медицинская паразитология и паразитарные болезни. 2016; 1: 17 - 25.

7. Балахонов С.В., Попова А.Ю., Мищенко А.И., Михайлов Е.П., Ежлова Е.Б., Демина Ю.В. и др. Случай заболевания человека чумой в Кош-Агачском районе Республики Алтай в 2015 г. Сообщение 1. Клинико-эпидемиологические и эпизоотологические аспекты. Проблемы особо опасных инфекций. 2016; $1: 55-60$.

8. Балахонов С.В., Афанасьев М.В., Шестопалов М.Ю., Остяк А.С., Витязева С.А., Корзун В.М. и др. Первый случай выделения Үеrsinia реstis subsp. pestis в Алтайском горном природном очаге чумы. Сообщение 1. Микробиологическая характеристика, молекулярно-генетическая и массспектрометрическая идентификация изолята. Проблемы особо опасных инфекций. 2013; 1 (115): 60 - 65.

9. Косилко С.А., Балахонов С.В., Корзун В.М., Чипанин Е.В., Денисов А.В., Михайлов Е.П. и др. Современная эпидемиолого-эпизоотологическая ситуация в Горно-Алтайском природном очаге чумы. Актуальные проблемы болезней, общих для человека и животных: Материалы Всероссийской научнопрактической конференции с международным участием. Ставрополь; 2012: 46.

10. Балахонов С.В., Корзун В.М., Вержуцкий Д.Б., Михайлов Е.П., Рождественский Е.Н., Денисов А.В. Первый случай выделения Үеrsinia реstis subsp. pestis в Алтайском горном природном очаге чумы. Сообщение 2. Вероятные пути и механизмы заноса возбудителя чумы основного подвида на территорию очага. Проблемы особо опасных инфекций. 2013; 2 (116): 5 - 10.

11. Кутырев В.В., Попова А.Ю., Ежлова Е.Б., Демина Ю.В., Пакскина Н.Д., Шарова И.Н. и др. Заболевание человека чумой в Горно-Алтайском высокогорном природном очаге в 2014 г. Сообщение 2. Особенности лабораторной диагностики и молекулярно-генетическая характеристика выделенных штаммов. Проблемы особо опасных инфекций. 2014; 4: 43 - 51.

12. Марамович А.С., Косилко С.А., Воронова Г.А., Иннокентьева Т.И., Базанова Л.П., Никитин А.Я. и др. Эпидемиологическое обоснование санитарной охраны территории Сибири от заноса чумы из Монголии. Проблемы особо опасных инфекций. 2007; 1 (93): $38-43$.

13. Адъяасурэн 3., Цэрэнноров Д., Мягмар Ж., Ганхуяг Ц., Отгонбаяр Д., Баяр Ц. и др. Современная ситуация в природных очагах чумы Монголии. Дальневосточный журнал инфекционный патологии. 2014; 25: 22 - 25.

14. Голубинский Е.П., Жовтый И.Ф., Лемешева Л.Б. О чуме в Сибири. Иркутск: Изд-во Иркут. гос. ун-та; 1987.

15. Стратегия социально-экономического развития Республики Алтай на период до 2028 г. Доступно на: http://www.city-strategy.ru/upload/document/ Resp_Altai_strategy2028.pdf.

16. Некипелов Н.В. Эпизоотология чумы в Монгольской Народной Республике. Известия Иркутского противочумного института. $1959 ; 22: 108$ - 243.

17. Бибиков Д.И., Берендяев С.А., Пейсахис Л.А., Шварц Е.А. Природные очаги чумы сурков СССР. М.: Медицина; 1973.

18. Никитин А.Я., Марамович А.С., Косилко С.А., Иннокентьева Т.И., Базанова Л.П., Балахонов С.В. и др. Эпизоотологическая характеристика природных очагов чумы Монголии в связи с разработкой мер защиты от завоза и распространения инфекции на территорию России. Проблемы особо опасных инфекций. 2007; 2 (94): 28 - 33.

19. Вержуцкий Д.Б. Пространственная организация населения хозяина и его эктопаразитов. Saarbrucken: Palmarium Academic Publishing; 2012.

\section{References}

1. Plague Manual: Epidemiology, Distribution, Surveillance and Control. WHO, Geneva; 1999. Available at: http://www.who.int/emc.

2. Kokushkin A.M. Social and biological aspects of plague epidemiology: PhD of med. sci. diss. Saratov; 1995 (in Russian).

3. Popov N.V., Bezsmertnyi V.E., Matrosov A.N., Knyazeva T.V., Kuznetsov A.A., Fedorov M.Yu. et al. Epizootic activity of natural plague foci in the territory of the Russian Federation in 2014 and prognosis for 2015. Probl. Osobo Opasn. Infek. [Problems especially dangerous infections]. 2015; 1: 10 - 17 (in Russian).

4. Balakhonov S.V., Korzun V.M., eds. Mountain-Altai natural plague focus: retrospective analysis, epizootological monitoring, current state. Novosibirsk: NaukaCenter [Science Center]; 2014 (in Russian).

5. Kutyrev V.V., Popova A.Yu., Ezhlova E.B., Demina Yu.V., Pakskina N.D., Shchuchinov L.V. et al. A human plague infection in the Gorno-Altai high-mountainous natural focus in 2014. Report 1. Epidemiological and epizootiological peculiarities of plague manifestations in the Gorno-Altai high-mountainous (Sailyugemsk) natural plague focus. Probl. Osobo Opasn. Infek. [Problems especially dangerous infections]. 2014; 4: 9 - 16 (in Russian).

6. Korzun V.M., Balakhonov S.V., Chipanin E.V., Denisov A.V., Mikhailov E.P., Mishchenko A.I. et al. A natural plague focus in Gornyi Altai: formation, development and functioning. Med. Parasitol. i Parasit. Bolesni. [Medical Parasitology and Parasitic Diseases]. 2016; 1: 17 - 25 (in Russian). 
7. Balakhonov S.V., Popova A.Yu., Mishchenko A.I., Mikhailov E.P., Ezhlova E.B., Demina Yu.V. et al. A case of human plague in Kosh-Agach district of Republic Altai in 2015. Report 1. Clinical-epidemiological and epizootological aspects. Probl. Osobo Opasn. Infek. [Problems especially dangerous infections]. 2016; 1: $55-60$ (in Russian).

8. Balakhonov S.V., Afanas'ev M.V., Shestopalov M.Yu., Ostyak A.S., Vityazeva S.A., Korzun V.M. et al. The first case of Yersinia pestis subsp. pestis isolation in Altai mountainous natural plague focus. Report 1. Microbiological characteristics, molecular-genetic and mass-spectrometric identification of the isolate. Probl. Osobo Opasn. Infek. [Problems especially dangerous infections]. 2013; 1 (115): 60 - 65 (in Russian).

9. Kosilko S.A., Balakhonov S.V., Korzun V.M., Chipanin E.B., Denisov A.V., Mikhailov E.P. et al. Current epidemiological-epizootological condition in Gorno-Altai natural plague focus. Actual problems of diseases common for humans and animals: Proceedings of All-Russian Sci.-Pract. Conf. with Intern. Participation. Stavropol; 2012: 46 (in Russian).

10. Balakhonov S.V., Korzun V.M., Verzhutsky D.B., Mikhailov E.P., Rozhdestvensky E.N., Denisov A.V. The first case of Yersinia pestis subsp. pestis isolation in the Altai mountainous natural plague focus. Report 2. Probable ways and mechanisms of plague agent basic subspecies importation into territory of the focus. Probl. Osobo Opasn. Infek. [Problems especially dangerous infections]. 2013; 2 (116): 5 - 10 (in Russian).

11. Kutyrev V.V., Popova A.Yu., Ezhlova E.B., Demina Yu.V., Pakskina N.D., Sharova I.N. et al. A human plague infection in the Gorno-Altai high-mountainous natural focus in 2014. Report 2. Peculiarities of laboratory diagnostics and molecular-genetic characterization of the isolated strains. Probl. Osobo Opasn. Infek. [Problems especially dangerous infections]. 2014; 4: 43 - 51 (in Russian).

12. Maramovich A.S., Kosilko S.A., Voronova G.A., Innokenteva T.I., Basanova L.P., Nikitin A.Ya. et al. Epidemiological explanation of sanitary protection of Siberia territory from plague importation from Mongolia. Probl. Osobo Opasn. Infek. [Problems especially dangerous infections]. $2007 ; 1$ (93): 38 - 43 (in Russian).

13. Adyaasuren Z., Tserennorov D., Myagmar Zh., Gankhuyag Ts., Otgonbayar D., Bayar Ts. et al. Current situation in natural plague foci in Mongolia. Far Eastern Zhurn. Infekt. Patologii. [Far East Journal of Infectious Diseases]. 2014; 25: 22 - 25 (in Russian).

14. Golubinsky E.P., Zhovtyi I.F., Lemesheva L.B. About plague in Siberia. Irkutsk: Irkutsk State University; 1987 (in Russian).

15. Strategy of social-economic development of Republic Altai till 2028. Available at: http://www.city-strategy.ru/upload/document/Resp_Altai_strategy 2028.pdf.

16. Nekipelov N.V. Plague epizootology in Mongolian People Republic. Izvestiya of Irkutsk Antiplague Institute. [News of Irkutsk Anti-Plague Institute]. 1959; 22 : $108-243$.

17. Bibikov D.I., Berendyaev S.A., Peisakhis L.A., Shwarts E.A. Natural plague foci in marmots in the USSR. Moscow: Meditsina. [Medicine]; 1973.

18. Nikitin A.Ya., Maramovich A.S., Kosilko S.A., Innokenteva T.I., Basanova L.P., Balakhonov S.V. et al. Epizootological characterization of natural plague foci in Mongolia in connection with development of protective measures from importation and dissemination of the infection in Russia. Probl. Osobo Opasn. Infek. [Problems especially dangerous infections]. 2007; 2 (94): 28 - 33.

19. Verzhutsky L.B. Spatial organization of a host and its ectoparasite populations. Saarbrucken: Palmarium Academic Publishing; 2012.

\title{
Эпидемиология ванкомицин-резистентных энтерококков в отделениях различного профиля
}

\author{
A.В. Любимова (Lubimova@gmail.com), Н.A. Шаляпина (najdenka13@mail.ru), \\ В.В. Колоджиева, С.А. Ряховских, О.В. Дмитриева, Т.В. Бродина, А.А. Шишмаков
}

ГБоУ ВПО «Северо-Западный государственный медицинский университет им. И.И. Мечникова", г. Санкт-Петербург

\section{Резюме}

Введение. Ванкомицин-резистентные энтерококки (vancomycin-resistant enterococci - VRE) являются одними из ведущих возбудителей инфекций, связанных с оказанием медицинской помощи. Для разработки эффективного эпидемиологического надзора необходимы сведения о частоте распространения VRE в отделениях различного профиля стационара.

Цель. Выявить отделения риска по распространению VRE в стационарах Санкт-Петербурга.

Материалы и методы. Исследование точечной превалентности колонизации/инфекции пациентов и контаминации объектов внешней среды было проведено в течение 2013 - 2014 годов в восьми отделениях различного медицинского профиля: реанимации новорожденных, патологии новорожденных, общей детской хирургии, трансплантации костного мозга (ТКМ для подростков), онкохирургии органов желудочно-кишечного тракта и молочной железы, гемодиализа (три отделения). В каждом отделений проводилось трехкратное ежемесячное микробиологическое исследование клинического материала от пациентов $(N=857)$ и смывов с объектов внешней среды ( $N=508)$. Верификацию устойчивости энтерококков к ванкомицину выявляли амплификацией кассет ванкомицин-резистентности vanA и VanB согласно методике, предложенной S. Dutka-Malen et al.

Молекулярно-генетическое типирование энтерококков методом ПЦР со “случайными" праймерами (RAPD-ПЦP) проводилось с применением универсального праймера R5 (5'-AACGCGCAAC-3') в концентрации 50 пмоль/мкл в соответствии регламента, предложенного B. Martin et al. VNTR-анализ осуществляли по J. Top et al.

Результаты. Колонизация пациентов и контаминация внешней среды VRE были выявлены только в отделениях онкогематологии (21,6 на 100 пациентов, 2,6 на 100 смывов) , реанимации новорожденных (16,7 на 100 пациентов, 8,5 на 100 смывов) и патологии новорожденных (34,6 на 100 пациентов, 3,3 на 100 смывов). Основными объектами внешней среды, на которых обнаружен VRE, были объекты медицинского назначения общие для всех пациентов (весы, пеленальный стол, процедурный стол, ручки кранов раковины) в отделениях реанимации и патологии новорожденных и объекты не медицинского назначения общие для пациентов (палатные столики, микроволновая печь и полки холодильников) в отделении онкогематологии. Результаты молекулярно-генетического типирования показали идентичность штаммов, выделенных от пациентов и из смывов с объектов внешней среды. Ванкомицинрезистентность за счет наличия кассеты vanA являлась доминирующейю Ванкомицинрезистентность за счет наличия кассеты vanA являлась доминирующей. 